\title{
Smoking in childhood
}

\author{
Beulah R. BeWley \\ M.D., M.Sc. \\ Department of Community Medicine, St Thomas's Hospital Medical School, London SE1
}

\begin{abstract}
Summary
A longitudinal study of smoking in a cohort of 6000 children aged 11-12 years is being carried out in Derbyshire. One of the main objectives is to discover the factors which influence children to take up smoking. Once such factors are determined intervention methods can be developed to discourage children from smoking which, it is hoped, will result in a reduction in mortality and morbidity from cigarette smoking.
\end{abstract}

\section{Introduction}

Many environmental factors existing in Western society today contribute towards mortality and morbidity from coronary heart disease (Williams and Wynder, 1976). Important among these is the smoking of cigarettes. The Framingham study has shown that with increasing consumption of cigarettes the incidence of clinical coronary heart disease increases and the effect can be seen at very low levels of cigarette consumption (Kannel, Castelli and McNamara, 1967). This effect of cigarette smoking is independent of other risk factors such as high blood pressure and raised serum cholesterol.

The effects of cigarette smoking on adults' health are well documented (Royal College of Physicians, 1962, 1971, 1977), but few attempts at reducing smoking have been successful. It would therefore be more sensible to begin preventive action before the habit has been formed (Ball and Turner, 1975). To do this we must first discover the extent of smoking in children and then identify the factors which encourage them to smoke. From these findings we may be able to design and evaluate intervention methods and create environments in which smoking is more actively discouraged.

Several studies have shown that many children experiment with cigarettes. Bewley (1971) found that $40 \%$ of Derbyshire primary schoolchildren had puffed their first cigarette before the age of nine. Seven per cent of boys and $2.5 \%$ of girls aged 10-11 years smoked one or more cigarettes a week.

Studies in adolescent populations (Bynner, 1969; Holland and Elliott, 1968; Holland et al., 1969) have shown that boys start smoking earlier than girls and they smoke more. In both sexes the amount smoked and the numbers who smoke increase with age. The prevalence rates in a national sample of boys attending secondary school (Bynner, 1969) were 4\% at 11.5 years increasing in successive years to $9 \%$, $17 \%, 27 \%$, and $38 \%$ at 15 years. A rapid increase of smoking was found amongst those who had left school at the age of 15 years (Todd, 1972).

All the studies mentioned have been crosssectional. In order to discover which children are more likely to start and to continue smoking a longitudinal study has been designed and is at present under way.

\section{Method}

The study which started in 1974 involves the Department of Community Medicine at St Thomas's Hospital, London, the Derbyshire Area Health and Education Authorities, and is financed by the Medical Research Council. In 1974 a cohort of about 6000 schoolchildren aged 11-12 years attending the first year in forty-eight secondary schools in Derbyshire was selected. Each year until 1978 they will complete a self-administered questionnaire. In 1974 a subsample of 14- to 15-year-olds were studied at the same time as the 11- to 12-year-olds and in 1977 when the 11-year-olds had reached the age of 14-15 years, another group of 11- to 12-year-olds were studied. This was to investigate any changes in smoking rates that occurred over the study period. In 1978 a separate group of controls will also be examined to discover if giving questionnaires yearly to the main group has had any effect on smoking. Parents and teachers are also being studied; parents only will complete questionnaires twice, in 1974 and in 1978.

\section{Results}

The preliminary results, confirming previous findings (Bewley, Halil and Snaith, 1973b; Bewley and Bland, 1976) showed that $6 \%$ of boys and $3 \%$ of girls aged 11-12 years were smoking one or more cigarettes per week (Table 1). Certain factors which are associated with children's smoking have also been identified. These include:

(1) Having parents who smoke - this appears to 
be sex-linked, since boys are more likely to smoke if their fathers smoke and girls if their mothers smoke.

(2) Having brothers and sisters who smoke. This does not appear to be sex linked, but is related to the number of siblings who smoke.

(3) Having friends who smoke, both inside and outside school.

(4) Truancy. Children who play truant are more likely to be smokers.

(5) Taking part in more social activities with mixed sex groups.

TABLE 1. Smoking prevalence rates in children aged 11-12 years in 1974

\begin{tabular}{lrrr}
\hline & $\begin{array}{c}\text { Boys } \\
\%\end{array}$ & $\begin{array}{c}\text { Girls } \\
\%\end{array}$ & $\begin{array}{c}\text { Total } \\
\%\end{array}$ \\
\hline Smokers & 6 & 3 & 4 \\
Experimental smokers & 49 & 38 & 43 \\
Non-smokers & 45 & 60 & 53 \\
Base numbers & 3098 & 3232 & 6330 \\
\hline
\end{tabular}

N.B. A smoker is defined as one who smokes one or more cigarettes a week.

\section{Discussion}

Early intervention in a number of different areas could be effective in preventing children taking up smoking and possibly becoming the habitual smokers of the future with the associated effects on health. With this and the preceding studies in mind there are two particular locations where children's smoking patterns may be influenced - in the school and in the home. In schools an effective health education programme would involve a substantial commitment from teachers to ensure that smokers and their peers recognize the hazards of smoking and act on this knowledge. Since there may be an association between teachers' smoking and children's smoking, teachers should be encouraged not to smoke in front of pupils either in school or during out-of-school activities.

Perhaps more difficult is effective intervention within the home. Parents should be encouraged either to stop smoking themselves or at least strongly to discourage their children from doing so. Clearly a ban on advertising, increases in cigarette prices and the introduction of more areas in restaurants, public transport and shops where smoking is banned are indicated. The same problems apply when attempting to influence the older siblings of child smokers.

As a follow-up to these studies the authors are planning, in collaboration with the Derbyshire Educational Authorities and the Health Education
Council, to monitor and evaluate a specific health education programme known as the 'Berkeley Pro-c ject' (Milne, Marshall-Mies and Colman, 1975) which will be introduced in a number of primary schools. It is hoped that this programme will be effective in increasing children's knowledge and흘 understanding of the consequences of smoking, but $\frac{\bar{\rho}}{\bar{\sigma}}$. it requires substantial teacher commitment.

We must make an aggressive attack on some unhealthy aspects of our present life styles particularly? with regard to such hazards as smoking. If such an? attack is effective, and reduced smoking rate results, $\overrightarrow{\vec{\omega}}$ we can expect an associated reduction in morbidity and mortality from coronary heart disease.

\section{References}

BALL, K.P. \& TURNER, R (1975) Realism in the prevention of coronary heart disease. Preventive Medicine, 4, 390.

BANKS, M., BEWLEY, B.R., BlaND, J.M., DEAN, J.R. \&. Pollard, V. (1977) A long-term study of smoking byc secondary schoolchildren. Archives of Disease in Child-o hood (in press).

BEWLEY, B.R. (1971) Children's smoking: A prevalencestudy of final year primary schoolchildren (10-11 years). $\bar{Z}$ Some factors associated with smoking at this age. M.Sc.ฏ Thesis, University of London.

BEWLEY, B.R. \& BLAND, J.M. (1976) Smoking and respiratory symptoms in two groups of schoolchildren. Preventife $\vec{\theta}$ Medicine, 5, 63.

BEWLEY, B.R., DAY, I. \& IDE, L. (1973a) Smoking by Childrên in Great Britain: a Review of the Literature. MRC/SSRC report.

BEWLEY, B.R., Halil, T. \& SNAITH, A.H. (1973b) Smoking by primary schoolchildren; prevalence and associated respiratory symptoms. British Journal of Preventiveo Medicine, 28, 37.

BYNNER, J.M. (1969) The Young Smoker. Government Social Survey. H.M. Stationery Office, London.

Holland, W.W. \& ElliotT, A. (1968) Cigarette smoking, respiratory symptoms and anti-smoking propaganda. Lancet, i, 41.

Holland, W.W., Halil, T., Bennett, A.E. \& Elliott, A. (1969) Factors influencing the onset of chronic respiratory음 disease. British Medical Journal, 2, 205.

KanNel, W.B., Castelli, W.B. \& MCNamara, P. (1967)음 Coronary profile: a 12 year follow-up in the Framingham Study. Journal of Occupational Medicine, 9, No. 12, 611.

Milne, A.M., Marshall-Mies, J. \& Colman, J.C. (1975)气 A Study of Impact of the School Health Curriculum Project on Knowledge, Attitude and Behavior of Teenage Students.윽 Contract No. 21-74-508. Department of Education and Public Affairs, Washington D.C.

Royal College of Physicians of London (1962) Smoking and Health. Pitman Medical, London.

Royal College of Physicians of London (1971) Smoking and Health Now. Pitman Medical, London.

Royal College of Physicians of London (1977) Smoking or Health. Pitman Medical, London.

ToDd, G.F. (1972) Statistics of smoking in the Unitedo Kingdom. Research Paper I, 6th edn. Tobacco Research Council, London.

WilliaMs, C.L. \& WYNDER, E.L. (1976) A blind spot in preventive medicine. Journal of the American Medical ${ }^{+}$ Association, 236, 2196. 